DOI: 10.22630/EIOGZ.2014.105.1

Zeszyty Naukowe Szkoły Głównej Gospodarstwa Wiejskiego

Ekonomika i Organizacja Gospodarki Żywnościowej nr 105, 2014: 5-16

Barbara Wyrzykowska

Katedra Ekonomiki i Organizacji Przedsiębiorstw

Szkoła Główna Gospodarstwa Wiejskiego w Warszawie

\title{
Polski sektor spółdzielczy w latach 2001-2011
}

\section{Wstęp}

Spółdzielczość na świecie odgrywała i odgrywa ważną rolę w rozwoju społeczno-gospodarczym poszczególnych krajów. Ma istotny wpływ na warunki życia wielu milionów ludzi. W krajach Unii Europejskiej funkcjonuje 235 tysięcy podmiotów spółdzielczych, które zatrudniają 4,48 miliona pracowników. Wyniki działalności spółdzielni mają wpływ na życie obywateli Europy i 140 milionów członków. Zainteresowanie problemami spółdzielczości można zaobserwować na szczeblu międzynarodowym, w szczególności odnotować należy [Raport 2010]:

- $\quad$ uchwałę ONZ nr 56/114 z 2001 roku oraz Raport Sekretarza Generalnego Organizacji Narodów Zjednoczonych z 2010 roku,

- dokument konsultacyjny Komisji Europejskiej p.n. Biała Księga o przedsiębiorstwach spółdzielczych z 2001 roku,

- zalecenie nr 193 Międzynarodowej Organizacji Pracy dotyczące promowania spółdzielni z 2002 roku,

- $\quad$ komunikat Komisji Wspólnot Europejskich o promowaniu spółdzielni w Europie z 2004 roku.

Istotną przyczyną skupiającą uwagę Komisji Europejskiej na zagadnieniach spółdzielczości jest pozytywna rola spółdzielni jako instrumentu wcielania w życie wielu celów Wspólnoty. Stąd między innymi przyjęcie statutu spółdzielni europejskiej oraz dyrektywy o zaangażowaniu pracowników w procesy podejmowania decyzji w spółdzielniach europejskich.

Polski sektor spółdzielczy to prawie 9 tysięcy czynnych podmiotów gospodarczych. Zrzeszają one ponad 8 milionów członków i zatrudniają około 400 tysięcy pracowników. Mają znaczący wpływ na życie kilku milionów obywateli naszego 
kraju [Raport 2010]. Sektor spółdzielczy, kierujący się w swojej działalności pewnymi wartościami i zasadami, okazał się dość odporny na zawirowania kryzysu światowego, szczególnie mocne okazały się banki spółdzielcze oraz spółdzielcze kasy oszczędnościowo-kredytowe. Celem badań, których wyniki zawarto w artykule, jest przedstawienie roli i znaczenia społeczno-gospodarczego sektora spółdzielczego w gospodarce polskiej w czasach kryzysu. W opracowaniu przyjęto tezę że spółdzielnie dzięki swej specyfice działania, gdzie członkowie są współwłaścicielami i jednocześnie klientami, stają się szczególnie ważne w czasach kryzysu oraz mogą stać się jednym z elementów stabilności gospodarczej państwa.

\section{Materiał i metoda}

Lata szybkich przemian społeczno-gospodarczych potwierdziły, że spółdzielczość w Polsce nie była przygotowana do funkcjonowania w warunkach realnego i globalnego rynku. Świadczą o tym liczne upadłości tych podmiotów, zwłaszcza w sektorze spółdzielczości wiejskiej ${ }^{1}$. W ostatnich latach udział sektora spółdzielczego w gospodarce narodowej Polski uległ wyraźnemu zmniejszeniu. W opracowaniu zawarto ocenę sektora spółdzielczego w gospodarce narodowej w latach 2001-2011 przez pryzmat pięciu podstawowych kategorii ekonomicznych, takich jak:

- udział sektora spółdzielczego w tworzeniu PKB,

- udział sektora spółdzielczego w produkcji globalnej gospodarki narodowej,

- udział sektora spółdzielczego w zatrudnieniu ogółem w gospodarce narodowej,

- udział sektora spółdzielczego w nakładach inwestycyjnych gospodarki narodowej,

- udział sektora spółdzielczego w wartości środków trwałych.

Artykuł $^{2}$ ma charakter przeglądowy. Dyskusja oparta jest głównie na analizie powszechnie dostępnych danych zawartych w publikacjach naukowych oraz w opracowaniu Głównego Urzędu Statystycznego (GUS) i danych Krajowej Rady Spółdzielczej. W artykule posłużono się metodą analizy porównawczej. Wyniki badań zestawiono w formie tabelarycznej.

\footnotetext{
${ }^{1}$ Od 1989 do 2007 roku liczba wszystkich spółdzielni wiejskich zmniejszyła się o 52,8\%.

${ }^{2}$ Inspiracją do napisania niniejszego artykułu było ogłoszenie przez Organizację Narodów Zjednoczonych roku 2012 Międzynarodowym Rokiem Spółdzielczości.
} 


\section{Miejsce sektora spółdzielczego w gospodarce narodowej Polski}

Analiza zmian pięciu wybranych kategorii ekonomicznych miała dać odpowiedź na pytanie, jak w latach 2001-2011 zmieniała się pozycja spółdzielczości w gospodarce narodowej. Udział dóbr i usług wytwarzanych przez sektor spółdzielczy w Polsce uległ zmniejszeniu. W 2001 roku stanowił 1,2\% PKB (tab. 1), a w 2011 roku tworzył niecały procent $(0,9 \%)$ PKB, gdy tymczasem w Europie było to średnio ok. 6\% [www.krs.org.pl]. Najwyższy udział tego sektora (1,9\%) odnotowano w 2008 roku w czasie pojawienia się kryzysu gospodarczego.

$\mathrm{Z}$ analizy danych zawartych w tabeli 1 wynika, że w latach 2001-2011 procentowy udział sektora spółdzielczego w produkcji globalnej gospodarki narodowej również systematycznie malał. W 2001 roku sektor spółdzielczy wytwarzał 2,3\% produkcji globalnej kraju, w 2011 roku nastąpił zaś spadek tego wskaźnika o 0,8 p.p.

Nasilenie się międzynarodowej konkurencji wymusza stały wzrost wydajności i produktywności. Z analizy i oceny wielkości produkcji globalnej i liczby zatrudnionych wynika, że w spółdzielniach te dwie kategorie ekonomiczne, w analizowanym okresie, wykazywały tendencje malejące. W konsekwencji powodowało to niską konkurencyjność spółdzielni i wypadanie ich z rynku. Od 2001 do 2007 roku liczba miejsc pracy w sektorze spółdzielczym utrzymywała się na stałym poziomie 2,5\%. Od 2008 roku liczba miejsc pracy ciagle malała,

\section{Tabela 1}

Udział sektora spółdzielczego w gospodarce narodowej Polski w latach 2001-2011 [\%]

\begin{tabular}{|l|c|c|c|c|c|c|c|c|c|c|c|}
\hline \multirow{2}{*}{ Wyszczególnienie } & \multicolumn{10}{|c|}{ Kolejne lata } \\
\cline { 2 - 13 } & 2001 & 2002 & 2003 & 2004 & 2005 & 2006 & 2007 & 2008 & 2009 & 2010 & 2011 \\
\hline $\begin{array}{l}\text { Udział w: } \\
\text { PKB }\end{array}$ & 1,2 & 1,2 & 1,6 & 1,6 & 1,0 & 0,9 & 1,0 & 1,9 & 0,9 & 1,0 & 0,9 \\
\hline $\begin{array}{l}\text { produkcji global- } \\
\text { nej gospodarki } \\
\text { narodowej }\end{array}$ & 2,3 & 2,3 & 2,5 & 1,9 & 1,9 & 1,7 & 1,7 & 1,5 & 1,6 & 1,6 & 1,5 \\
\hline $\begin{array}{l}\text { zatrudnieniu } \\
\text { ogółem }\end{array}$ & 2,5 & 2,5 & 2,5 & 2,5 & 2,5 & 2,5 & 2,5 & 2,1 & 2,1 & 2,0 & 1.9 \\
\hline $\begin{array}{l}\text { nakładach inwe- } \\
\text { stycyjnych gospo- } \\
\text { darki narodowej }\end{array}$ & 4,4 & 3,4 & 2,7 & 3,1 & 2,7 & 3,0 & 2,0 & 1,8 & 1,5 & 4,1 & 1,3 \\
\hline $\begin{array}{c}\text { wartości środków } \\
\text { trwałych }\end{array}$ & 6,8 & 8,5 & 8,1 & 7,8 & 7,5 & 7,2 & 6,6 & 5,7 & 4,9 & 4,1 & 3,7 \\
\hline
\end{tabular}

Źródło: Opracowanie własne na podstawie Roczników Statystycznych GUS 2002-2012. 
a był to skutek przede wszystkim zmniejszenia liczby spółdzielni oraz spadku poziomu przeciętnego zatrudnienia w tych przedsiębiorstwach. W 2011 roku udział sektora spółdzielczego w zatrudnieniu ogółem wyniósł 1,9\% i był najniższy w całym analizowanym okresie.

O rozwoju branży świadczą nakłady inwestycyjne. Na podstawie danych zawartych w tabeli 1 widać wyraźnie, że udział sektora spółdzielczego w nakładach inwestycyjnych spadł drastycznie. W 2011 roku wartość tego wskaźnika osiągnęła poziom $1,3 \%$. Nawet przystąpienie Polski do UE nie przyczyniło się do wzrostu tych nakładów. Jedyną prężnie rozwijającą się branżą była spółdzielczość mleczarska jako efekt nałożonych na sektor mleczarski wysokich wymagań sanitarno-weterynaryjnych oraz konieczność uzyskiwania certyfikatów jakości.

Nakłady inwestycyjne wiążą się również z nakładami na środki trwałe. Wartość środków trwałych w latach 2001-2011 również zmniejszyła się z 6,8 do $3,7 \%$. Spadki wartości środków trwałych były niewątpliwie wynikiem likwidacji spółdzielni. Często dochodziło do nadużyć, spółdzielnie likwidowano po to, by przejąć ich majątek. Pozwala na to polskie prawo. W spółdzielniach nie odnawia się środków produkcji, skazują się więc one na stopniowe wykluczenie z rynku.

Przytoczone dane świadczą o utrzymywaniu się w spółdzielniach różnych typów tradycyjnych kierunków produkcji, braku postępu technicznego i ich niskiej konkurencyjności względem przedsiębiorstw sektora prywatnego (spółek kapitałowych). Sektor prywatny rozwijał się bardzo dynamicznie, co potwierdza jego wysoki udział w nakładach inwestycyjnych gospodarki narodowej [Mierzwa 2010].

\section{Zmiany w liczebności spółdzielni}

Spółdzielnie, jako jedna z form współpracy gospodarczej ludzi, pod względem organizacji i celów mają cechy podobne do towarzystw ubezpieczeń wzajemnych i stowarzyszeń, stąd zaliczane są do sektora gospodarki społecznej. Spółdzielnie działają niemal w każdej dziedzinie życia społeczno-gospodarczego, dowodzi tego światowa praktyka spółdzielcza. Działają głównie w obszarach zbytu i zaopatrzenia rolniczego, finansów, handlu hurtowego i detalicznego, opieki zdrowotnej, mieszkalnictwa i ubezpieczeń. Obecnie wkraczają jednak i na nowe pola działalności, takie jak technologie informacji i komunikacji, turystyka czy kultura. Ilość i różnorodność branż spółdzielczych świadczy o dużych możliwościach spółdzielczego gospodarowania. Pomimo dużej liczby podmiotów ich udział w rynku w Polsce jest nieporównywalnie mniejszy niż w wielu krajach 
Europy Zachodniej ${ }^{3}$. Jedyną porównywalną branżą jest spółdzielcze mleczarstwo [Mierzwa 2009].

Polskie spółdzielnie nie wkroczyły jeszcze w wiele obszarów, w których funkcjonują spółdzielnie w Europie i na świecie. Spółdzielczość polska pomimo powstania nowych branż utrzymuje w dużym stopniu swój tradycyjny podział ukształtowany w okresie gospodarki centralnie zarządzanej. Należy podkreślić, że działalność spółdzielni w poszczególnych branżach uległa poważnemu zróżnicowaniu. Część spółdzielni zrezygnowała z niektórych obszarów działania na

Tabela 2

Zmiana liczby spółdzielni w Polsce w latach 2001, 2008 i 2012

\begin{tabular}{|l|c|c|c|c|}
\hline Branża spółdzielcza & 2001 & 2008 & $\begin{array}{c}\text { Stan na } \\
1.03 .2012\end{array}$ & $\begin{array}{c}\text { Dynamika } \\
\text { zmian [\%] } \\
2012 / 2001\end{array}$ \\
\hline Spółdzielczość Spożywców „Społem” & 427 & 393 & 372 & 87,1 \\
\hline Gminne Spółdzielnie „Samopomoc Chłopska” & 1992 & 1617 & 1500 & 75,3 \\
\hline Spółdzielnie Mleczarskie & 335 & 218 & 184 & 54,9 \\
\hline Spółdzielnie Ogrodniczo-Pszczelarskie & 188 & 131 & 110 & 58,5 \\
\hline Rolnicze spółdzielnie produkcyjne & 1598 & 1175 & 1065 & 66,6 \\
\hline Spółdzielnie Kółek Rolniczych & 1427 & 1070 & 958 & 67,1 \\
\hline Banki Spółdzielcze & 880 & 594 & 584 & 66,4 \\
\hline Spółdzielnie Mieszkaniowe & 3948 & 4306 & 4326 & 109,6 \\
\hline $\begin{array}{l}\text { Spółdzielnie Pracy i Usług oraz Spółdzielnie } \\
\text { Budowlane }\end{array}$ & 2092 & 1398 & 1235 & 59,5 \\
\hline Spółdzielnie Inwalidów i Niewidomych & 436 & 335 & 296 & 68 \\
\hline Spółdzielnie Rękodzieła Artystycznego „Cepelia” & 62 & 39 & 29 & 46,8 \\
\hline Spółdzielnie Rzemiosła & 390 & 289 & 240 & 61,5 \\
\hline Spółdzielnie Socjalne & - & 96 & 376 & 392 \\
\hline Spółdzielnie Producentów Rolnych & - & 56 & 257 & 459 \\
\hline Spółdzielcze Kasy Oszczędnościowo-Kredytowe & 113 & 85 & 80 & 71 \\
\hline Razem & 13973 & 11802 & 11612 & 83,1 \\
\hline
\end{tabular}

Źródło: Opracowanie własne na podstawie bazy danych Krajowej Rady Spółdzielczej oraz Raportu rocznego za 2010 rok, KRS, Warszawa, s. 10.

\footnotetext{
${ }^{3}$ Jak stwierdza Komisja Europejska w Białej Księdze, spółdzielnie są ważnym elementem nowoczesnej gospodarki rynkowej. Udział spółdzielni w działalności gospodarczej jest wyższy w zaawansowanych gospodarkach rynkowych niż w tych, które są mniej zaawansowane i przyczyniły się one do wyższego poziomu rozwoju. W USA na przykład, ponad 100 milionów osób jest członkiem 47000 spółdzielni, ponad 20 z tych spółdzielni ma roczną sprzedaż przekraczającą 1 miliard dolarów każda. W państwach członkowskich UE (dane dla „15-ki”) udział spółdzielczości ma znaczący udział w rynku w ważnych branżach, np. udział w rynku rolnym wynosi średnio $60 \%$.
} 
rzecz innych, inne zaś podjęły działalność wcześniej dla siebie nieznaną. Aktualnie wyróżniamy 15 branż spółdzielczych, trzy z nich: spółdzielnie socjalne, spółdzielnie producentów rolnych, Spółdzielcze Kasy Oszczędnościowo-Kredytowe powstały już po zmianach ustrojowych [V Kongres Spółdzielczości 2012]. W pozostałych branżach spółdzielczych zaszły daleko idące zmiany. Pomimo zachowania tradycyjnej nazwy prowadzą na ogół o wiele bardziej zróżnicowaną działalność niż przed 1990 rokiem.

W okresie urynkowienia gospodarki rola spółdzielczości znacznie zmalała. Zmianę w liczbie spółdzielni przedstawia tabela 2. Jak wynika z przedstawionych danych, w ostatnich latach liczba spółdzielni systematycznie zmniejszyła się z 13973 spółdzielni w 2001 roku do 11612 spółdzielni na początku 2012 roku. Jednak zmniejszenie liczby spółdzielni w poszczególnych branżach miało różne przyczyny i skutki. Duży spadek liczby samodzielnie działających banków spółdzielczych wynikał przede wszystkim z konieczności łączenia się banków w celu spełnienia wymogów, co spowodowało, że cały sektor wzmocnił swoją pozycję. Podobny charakter zmian wystąpił w spółdzielczości mleczarskiej, która unowocześniła bazę przetwórczą i zachowała udział w rynku wynoszący 75-80\% [Boguta 2011].

Spółdzielnie odgrywają ważną rolę w rozwoju ekonomicznym i społecznym oraz w ułatwianiu tworzenia miejsc pracy. Należą do nich przedsiębiorstwa zarówno niewielkiej skali, jak i prowadzące interesy na ogromną skalę na całym świecie. Od kilku lat w Polsce powstają spółdzielnie socjalne. Z założenia mają spełniać ważną rolę w aktywizacji zawodowej osób mających problemy ze znalezieniem zatrudnienia na rynku pracy. Fakt, że zaledwie 1/3 zarejestrowanych spółdzielni socjalnych jest aktywna świadczy, że warunki prawne ich funkcjonowania wymagają analizy. Spółdzielnie socjalne to branża, która szczególnie w czasach kryzysu ma wiele do zaoferowania, tworzone są na rzecz osób wykluczonych społecznie oraz takich, które mają największe trudności z funkcjonowaniem w życiu społecznym i zawodowym, w tym głównie na rynku pracy.

Od 2000 roku powstają grupy producentów rolnych, obecnie jest ich około 500, 30\% z nich funkcjonuje w formie spółdzielczej.

Proces zmian w spółdzielczości polskiej obarczony jest przeszłością okresu gospodarki centralnie zarządzanej. Spółdzielczość przeszła bardzo trudny i niekorzystny dla siebie okres przemian. Straty w potencjale ekonomicznym i społecznym sięgają połowy potencjału sprzed 1990 roku [Skoczek 2013]. Daje się zauważyć dość znaczne zróżnicowanie stanu i kondycji ekonomicznej spółdzielni w poszczególnych regionach. Spółdzielnie ekonomicznie silniejsze, głównie działające w regionach gospodarczo bardziej rozwiniętych, bądź te, które zdołały przystosować się do nowych warunków umocniły swoją pozycję i często 
rozwinęły swoją działalność. Wystąpiła jednak dość liczna grupa spółdzielni, które prowadziły politykę „na przetrwanie” i szybko znalazły się w trudnej, często schyłkowej sytuacji. Nie poszukiwały one sposobów na wzmocnienie swojej pozycji poprzez integrację czy fuzję, lecz uciekały w proces likwidacji. Najczęściej dochodziło wówczas do przejęcia dorobku kilku pokoleń przez wąską grupę osób, jednak duża część spółdzielni przeszła ogromnym wysiłkiem proces modernizacji i restrukturyzacji. Wiele z nich stanowi dziś nowoczesne przedsiębiorstwa dobrze służące swoim członkom i lokalnym środowiskom. Rozpoczęły one proces koncentracji potencjału i integracji pionowej. Obecnie można mówić nie tylko o pojedynczych nowoczesnych spółdzielniach, ale o całych branżach, jak mleczarstwo, mieszkalnictwo czy bankowość. Dzięki właściwej polityce państwa sukces odniosły Banki Spółdzielcze i Spółdzielcze Kasy Oszczędnościowo-Kredytowe, które mają jednolitą strukturę i zaspokajają potrzeby finansowe ok. 2,6 milionów swoich członków.

\section{Rola bankowości spółdzielczej w czasie kryzysu}

W sektorze bankowo-finansowym funkcjonują dwie struktury: banki spółdzielcze mające blisko 150-letnią tradycję oraz Spółdzielcze Kasy Oszczędnościowo-Kredytowe, które powstały stosunkowo niedawno. Cechą specyficzną polskiej spółdzielczości bankowej jest jej narodowy charakter, który miał szczególne znaczenie w okresie zaborów dla utrzymania i rozwoju polskiego stanu posiadania. Po blisko 100 latach ta specyficzna cecha banków ma swoje nowe znaczenie. Kryzys finansowy, którego doświadczamy, odkrywa niejako na nowo walory bankowego systemu spółdzielczego. Globalna gospodarka oznaczająca swobodę przepływu kapitału i jego koncentrację niesie ze sobą także zagrożenia związane $\mathrm{z}$ trudnościami kontroli tych procesów oraz anonimową własnością. W tym kontekście rola i misja banków spółdzielczych - mających znanych z imienia i nazwiska właścicieli zakorzenionych w lokalnych wspólnotach będących pod kontrolą społeczną swoich członków - ma dla społeczno-gospodarczego rozwoju środowisk, w których funkcjonują znaczenie trudne do przecenienia. Integrują one ludzi i ich drobne kapitały, wspierają indywidualne i zbiorowe inicjatywy gospodarcze i społeczne, tworzą większe poczucie bezpieczeństwa i są znaczącym stabilizatorem rynku finansowego. Banki spółdzielcze stanowią obecnie największą strukturę bankową w kraju $\mathrm{i}$ to jest poważnym atutem w walce konkurencyjnej z innymi bankami komercyjnymi [Boguta 2011].

W Polsce istnieje ponad pół tysiąca banków spółdzielczych (por. tab. 2). Co trzecia jednostka bankowa to bank spółdzielczy, wiele z nich stanowi silne 
instytucje finansowe ${ }^{4}$. Po wielu zmianach organizacyjnych i strukturalnych związanych z przemianami politycznymi i społeczno-gospodarczymi banki spółdzielcze zrzeszone są obecnie w trzech bankach zrzeszających: Banku Polskiej Spółdzielczości S.A., Gospodarczym Banku Wielkopolski S.A. oraz Mazowieckim Regionalnym Banku S.A. Banki spółdzielcze obsługują środowiska lokalne: rolników, drobną przedsiębiorczość i samorządy, środki przez nie wypracowane służą rozwojowi środowiska, w którym funkcjonują. Cieszą się zaufaniem i uznaniem wśród swoich klientów. W dobie pojawiających się zagrożeń właściwych dla globalnej gospodarki stanowią ostoję stabilizacji i bezpieczeństwa [Raport 2010].

W sytuacji kryzysu finansowego część społeczeństwa traci zaufanie do banków komercyjnych i instytucji finansowych działających na rynkach globalnych, co powoduje wzrost zaufania do lokalnych instytucji, takich jak banki spółdzielcze i Spółdzielcze Kasy Oszczędnościowo-Kredytowe.

Bankowość spółdzielcza rzadko udziela kredytów w walutach obcych i posiada rygorystyczne zasady badania zdolności kredytowej oraz określenia zabezpieczeń dla kredytów, zwłaszcza walutowych. Dzięki temu banki mogą skutecznie egzekwować wierzytelności. Bezpieczeństwo banków spółdzielczych wynika również z tego, że ich klientami są członkowie, czyli ich właściciele. Banki te w porównaniu z bankami komercyjnymi mają wyższy wskaźnik wypłacalności, wysoką nadwyżkę depozytów nad kredytami, niski wskaźnik kredytów zagrożonych. Bezpieczne lokaty w bankach nie są tak dochodowe jak w bankach komercyjnych. Jednak jest to cena, jaką płacą banki i ich klienci za bezpieczeństwo lokat oszczędnościowych i innych produktów bankowych.

Powstałe 21 lat temu Spółdzielcze Kasy Oszczędnościowo-Kredytowe (SKOK-i) znakomicie wpisały się w polski rynek usług finansowych. Ta najmłodsza dziedzina polskiej spółdzielczości finansowej nawiązuje do przedwojennej tradycji ruchu samopomocy finansowej dr. Stefczyka, korzystając jednocześnie z najlepszych praktyk nowoczesnych systemów unii kredytowych w Europie, Kanadzie i Stanach Zjednoczonych. SKOK-i cały czas zyskują na znaczeniu w gospodarce narodowej [Raport 2010]. O wzroście zainteresowania instytucjami typu SKOK świadczą dane przedstawione w tabeli 3.

Z danych zawartych $\mathrm{w}$ tabeli wynika, że systematycznie wzrasta liczba kas z oddziałami, z 1757 w 2008 roku do 1942 w 2013 roku. Również liczba członków zwiększyła się, na początku czerwca 2013 przekroczyła 2,6 miliona. W analizowanym okresie nastąiło podnoszenie wartości aktywów, depozytów oraz pożyczek, co świadczy o wzroście znaczenia kas. W ciągu niespełna

\footnotetext{
${ }^{4}$ Wielkość bankowości spółdzielczej można pokazać na przykładzie Krakowskiego Banku Spółdzielczego, który przyłączył 23 mniejsze banki spółdzielcze.
} 
Tabela 3

Liczba kas, członków oraz wysokość depozytów, pożyczek w latach 2001-2013

\begin{tabular}{|c|c|c|c|c|c|}
\hline Lata & $\begin{array}{c}\text { Liczba kas } \\
\text { (z oddziałami) }\end{array}$ & $\begin{array}{c}\text { Liczba } \\
\text { członków } \\
\text { [tys.] }\end{array}$ & $\begin{array}{c}\text { Aktywa } \\
\text { [tys. zł] }\end{array}$ & $\begin{array}{c}\text { Depozyty } \\
\text { [tys. zł] }\end{array}$ & $\begin{array}{c}\text { Pożyczki } \\
\text { [tys. zł] }\end{array}$ \\
\hline 2001 & 680 & 525 & 1752316 & 1558436 & 1235554 \\
\hline 2003 & 1285 & 924 & 3343652 & 3111630 & 2212939 \\
\hline 2005 & 1553 & 1395 & 5329024 & 4989570 & 3502929 \\
\hline 2007 & 1663 & 1669 & 7324988 & 6705001 & 5147320 \\
\hline 2008 & 1757 & 1856 & 9446921 & 8604073 & 6932627 \\
\hline 2009 & 1801 & 2026 & 11637339 & 10842415 & 8411273 \\
\hline 2011 & 1934 & 2315 & 15598200 & 14518197 & 10906655 \\
\hline $\begin{array}{c}\text { do } \\
06.2013\end{array}$ & 1942 & 2648 & 18328880 & 17011509 & 11676943 \\
\hline
\end{tabular}

Źródło: Opracowanie własne na podstawie www.skok.pl (dostęp: 24.10.2013).

sześciu lat, od 2008 roku, kiedy rozpoczął się kryzys, do połowy 2013 roku wartość aktywów i depozytów wzrosła prawie dwukrotnie, odpowiednio o 94 i 97,7\%, wartość udzielanych pożyczek wzrosła natomiast o 68,4\%, i to w sytuacji, kiedy banki komercyjne ograniczały dostęp do kredytów.

SKOK-i są znaczącym i cenionym pracodawcą, zwłaszcza w mniejszych ośrodkach miejskich, wspierają samozatrudnienie i rozwój małego biznesu - coraz więcej kas ma specjalne linie pożyczkowe dla przedsiębiorców oraz wyodrębniane dla nich wygodne rachunki. Działania prowadzone przez kasy w sposób istotny ożywiają gospodarkę poprzez wzrost popytu konsumentów/ /członków SKOK na towary i usługi. O sukcesie tych organizacji przesądza fakt, że SKOK tworzą ludzie, którzy wspólnie oszczędzają i pożyczają sobie pieniądze. Jest to organizacja ludzi, a nie kapitału. Działają dla dobra członków, a nie dla zysku, dając szansę na korzystanie z tanich i dostępnych usług finansowych. Spółdzielcze Kasy Oszczędnościowo-Kredytowe zawsze oferowały i oferują korzystniejsze kredyty i lokaty niż czyniły to banki. SKOK-i gwarantują też lepsze od bankowych bezpieczeństwo zgromadzonych oszczędności. Nie ograniczają się do działań wyłącznie ekonomicznych, lecz także prowadzą działalność charytatywną. Pomoc finansową otrzymuje wiele osób i instytucji, na inspirację i wsparcie mogą liczyć organizatorzy ważnych wydarzeń kulturalnych. W ciągu dotychczasowej działalności SKOK-i przekazały już wiele milionów złotych na akcje charytatywne, finansowo oraz rzeczowo wspomagały i nadal wspomagają domy dziecka, przedszkola oraz dzieci z najbiedniejszych rodzin. Nie zapominają także o dzieciach niepełnosprawnych, oferując środki finansowe, jak również dofinansowując wyjazdy dzieci 
z rodzin najuboższych na kolonie. Dowody uznania, z jakimi SKOK-i spotykają się w kraju i na arenie międzynarodowej, są w dużej mierze wynikiem tych właśnie prospołecznych działań podejmowanych przez SKOK-i [www.pieniadze. fakt.pl].

SKOK-i są przykładem realizacji dobrych praktyk finansowych, popartych dynamicznym rozwojem oraz zaawansowaniem technologiczno-instytucjonalnym. Według Światowej Rady Związków Kredytowych, SKOK-i są najbardziej dynamicznie rozwijającym się ruchem unii kredytowych na świecie. System SKOK wspiera rozwój partnerskich unii kredytowych szczególnie w Europie Środkowej i Wschodniej we współpracy z MSZ, Światową Radą Związków Kredytowych (WOCCU) oraz Programem Narodów Zjednoczonych ds. Rozwoju (UNDP). Kasa Krajowa jest członkiem Międzynarodowego Związku Spółdzielczego z siedzibą w Genewie oraz Światowej Rady Związków Kredytowych z siedzibą w Madison [Raport 2010].

\section{Przesłanki rozwoju spółdzielczości w polskim systemie społeczno-gospodarczym}

Za prowadzeniem polityki sprzyjającej rozwojowi spółdzielczości przemawiają dwie główne przesłanki. Pierwsza z nich dotyczy rynku jako najważniejszego elementu gospodarki kapitalistycznej. Walorem wolnego rynku jest jego różnorodność polegająca na możliwości funkcjonowania obok siebie podmiotów gospodarczych o różnej formie prawnej i różnych celach działania. Wielość funkcjonujących podmiotów o różnym statusie prawnym, odmiennych celach prowadzonej działalności i różnej formie własności znacznie wzbogaca rynek, czyni go bardziej efektywnym i przyjaznym dla ludzi. Różnorodność struktur gospodarczych ma duże znaczenie dla bezpieczeństwa społecznego i trwałego rozwoju [Raport 2010]. Kryzys finansowy i gospodarczy pokazuje, że spółdzielnie mogą przyczynić się znacznie do stabilizacji rynków, w tym rynku finansowego.

Druga przesłanka, nie mniej ważna, związana jest z budową społeczeństwa obywatelskiego. Rząd RP przyjął Strategię wspierania społeczeństwa obywatelskiego na lata 2007-2013. Formułuje ona cztery priorytety, których realizacja warunkuje tworzenie społeczeństwa obywatelskiego. Są to: aktywni i świadomi obywatele oraz aktywne wspólnoty lokalne, silne organizacje pozarządowe w dobrym państwie, integracja społeczna oraz ekonomiczna. Spółdzielnie należą do grona organizacji zdolnych do urzeczywistniania tych priorytetów w szerszej skali. Zasadnicze cechy funkcjonowania spółdzielni są praktycznie tożsame z priorytetami Strategii [Raport 2010]. Podstawę ich 
działania stanowi świadomość i aktywność członków, pracują one na rzecz swoich członków oraz angażują się w rozwiązywanie problemów społecznych, mają wspólnotowy charakter, a decyzje podejmowane są demokratycznie na zasadzie dialogu, stanowią zbiorową formę przedsiębiorczości opartą na współpracy, samopomocy i współdziałaniu. Przyczyniają się więc do podnoszenia zawodowej i społecznej aktywności obywateli [www.ur.edu.pl].

\section{Wnioski}

Z analizy danych wynikają następujące wnioski:

1. Udział spółdzielczości w tworzeniu produktu krajowego brutto spadł do niespełna 1\%, przy średniej w Unii Europejskiej wynoszącej ok. 6\%. Udział sektora spółdzielczego $\mathrm{w}$ produkcji globalnej w analizowanym okresie obniżył się 0,8 p.p. Znacznie zmalała liczba zatrudnionych w spółdzielniach, czego przyczyną było zmniejszenie liczby spółdzielni oraz spadek przeciętnego zatrudnienia w tych podmiotach. Udział sektora w nakładach inwestycyjnych gospodarki narodowej w 2011 roku wynosił 1,3\% - obniżył się 3-krotnie. Zmniejszyła się również wartość środków trwałych z 6,8 do $3,7 \%$.

2. W analizowanych 10 latach liczba spółdzielni zmniejszyła się o 2361 podmiotów. Zmiany liczebności spółdzielni w Polsce dokonywały się pod wpływem takich procesów, jak: likwidacja, podział istniejących spółdzielni (głównie mieszkaniowych), powstanie nowych spółdzielni w nowych dziedzinach (SKOK-i, spółdzielnie socjalne, spółdzielnie producentów rolnych), łączenie spółdzielni (banki, spółdzielnie mleczarskie).

3. Sytuację i pozycję banków spółdzielczych z punktu widzenia bezpieczeństwa ekonomicznego należy ocenić jako zadowalającą i stabilną, co jest szczególną wartością w dobie kryzysu. SKOK-i są dobrym dowodem na to, że spółdzielcza oferta może być atrakcyjna dla ludzi w każdym czasie i w każdych warunkach. Jako instytucje samopomocowe stanowią ważny czynnik zaufania i bezpieczeństwa społecznego. Mimo kryzysu finansowego i gospodarczego osiągają wzrostową liczbę depozytów i udzielanych kredytów.

4. Na spółdzielczości spoczywa wiele funkcji i zadań, które w czasach kryzysu nie są możliwe do zastąpienia przez inne podmioty gospodarcze. Większość spółdzielni jest niezbędna, aby wyrównywać nierówności społeczne i gospodarcze. Spółdzielczość można uznać za ogniwo postępu społecznego i gospodarczego, które również przyczynia się do ograniczania bezrobocia. Dlatego konieczne jest właściwe wykorzystanie tej formy gospodarowania do rozwiązywania wielu problemów społecznych i gospodarczych. 


\title{
Literatura
}

BOGUTA W. (red.): Spóldzielczość wiejska. Wyd. Spółdzielcze, Warszawa 2011.

KAWA M., KUŹNIAR W.: Rola spółdzielczości jako instytucji w przeciwdziałaniu nierówności ekonomicznych i społecznych, www.ur.edu.pl/pliki/Zeszyt15/28.pd (dostęp: 10.10.2013).

KRYSIAK I.: Informacja o sektorze spółdzielczym w Polsce. Fundacja Inicjatyw Społeczno-Ekonomicznych, Warszawa 2006.

MIERZWA D.: Przedsiębiorstwo spóldzielcze - dotychczasowe doświadczenia i kierunki rozwoju. Roczniki Nauk Rolniczych, Seria G, t. 96, z. 3, 2009.

MIERZWA D.: Przedsiębiorstwo spółdzielcze - tradycja i współczesność. UWP, Wrocław 2010.

Raport o spółdzielczości polskiej. KRS, Warszawa 2010.

SKOCZEK T.: Spółdzielczość w budowie społeczeństwa obywatelskiego - historia i wspótczesność. KRS, Warszawa 2013.

Spóldzielcy u Prezydenta RP, www.krs.org.pl/index.php?option=com_(dostęp: 22.10.2013).

Spóldzielczość finansowa jest popierana przez społeczeństwa, www. pieniadze.fakt.pl/kto-jestodpowiedzialny-za-obecny-kryzys-finansowy,artykuly,417778,1.htm (dostęp: 15.10.2013).

GUS: Roczniki Statystyczne: lata: 2002-2012, Warszawa.

Sprawozdanie z działalności Krajowej Rady Spóldzielczej za lata 2009-2012. V Kongres Spółdzielczości 27-28 listopada. KRS, Warszawa 2012.

www.skok.pl (dostęp: 24.10.2013).

\section{Polish cooperative sector in the years 2001-2011}

\begin{abstract}
This paper assesses the position of the cooperative sector in Polish national economy in the years 2001-2011. The study is based mainly on publicly available information such as scientific publications and databases of the Central Statistical Office (GUS) and the National Council for Cooperative. The article used comparative analysis. The analysis showed that in recent years the share of the cooperative sector in the national economy declined. The number of cooperatives has steadily decreased, having different causes and effects depending on the industry. Financial and economic crisis has shown that cooperative banking plays an important role in the stabilization of the financial market.
\end{abstract}

